UDC: 615.1:543.61

DOI: $10.15587 / 2519-4852.2019 .169511$

\title{
DEVELOPMENT OF THE METHOD OF SIMULTANEOUS QUANTITATIVE DETERMINATION OF LORATADINE AND AUXUILARY SUBSTANCES IN THE COMBINED SYRUP "LORATADIN+"
}

\author{
(C) A. Glushchenko, I. Bezruk, L. Ivanauskas, V. Georgiyants
}

\begin{abstract}
Мета. Метою представленого дослідження була розробка методики одночасного визначення лоратадину та допоміжних речовин - метилпарагідроксибензоату та пропілпарагідроксибензоату в комбінованому сиропі «Лоратадин+» у присутності ласкавия золотистого трави екстракту.

Матеріали і методи. Liquid chromatography separation was performed using a Shimadzu Nexera X2 LC30AD HPLC system (Shimadzu, Japan) composed of a quaternary pump, an on-line degasser, a column temperature controller, the SIL-30AC autosampler (Shimadzu, Japan); the CTO-20AC thermostat (Shimadzu, Japan) as well as the SPD-M20A diode array detector (DAD).

Результати і обговорення. Ідентифікацію основного компоненту та домішок у комбінованому засобі проводили шляхом визначення часів утримування піків лоратадину, метилпарагідроксибензоату і пропілпарагідроксибензоату на хроматограмі випробовуваного розчину, одержаній при їх кількісному визначенні, які співпадали з часами утримування відповідних піків на хроматограмі розчину порівняння.

При розробиі методики кількісного визначення встановлено, щзо з використанням градієнтного режиму спостерігалось краще розділення між сполуками, коефіцієнт розділення між піками метилпарагідроксибензоату та найближчих до нього піків став більщим ніж 2.5, у випадку пропілпарагідроксибензоата цей показник становив більше 3.

Для підтвердження коректності запропонованого методу було проведено валідаційні дослідження згідно з вимогами ДФУ. Встановлено, щуо невизначеність пробопідготовки становить для лоратадину 1,5\%, для метилпарагідроксибензоату - 1,47\%, для пропілпарагідроксибензоату - 1,53 \%, щзо не перевищує критерії прийнятності. Специфічність методики підтверджена шляхом порівняння хроматограмрозчину порівняння, випробовуваного розчину і хроматограми бланк-розчину. Вимоги до лінійності методики виконувалися на всьому діапазоні концентрацій для лоратадину і обох допоміжних речовин. Коефіцієнти кореляції становили 0,9999, 0,9999 та 0,9995 відповідно. Правильність методики виконувалась за двома критеріями - практичною та статистичною незначущістю, що були визначені в ході експериментальних досліджень. Результати оцінки внутрішньолабораторної прецизійності показали відповідність одержаних значень довірчого інтервалу середнього результату критерію прийнятності. За результатами визначення робасності встановлено, щуо для оптимальних умов хроматографування можна використовувати свіжоприготований розчин порівняння протягом 24 год.
\end{abstract}

Висновки. Розроблена методика одночасного кількісного визначення лоратадину та допоміжних речовин - метилпарагідрокисбензоату та пропілпарагідроксибензоату у сиропі комбінованому «Лоратадин+». Визначено умови, щуо дозволяють коректно визначити всі компоненти в присутності екстракту ласкавия золотистого трави. Коректність методики підтверджено валідаційними дослідженнями

Ключові слова: лоратадин, метилпарагідрокисбензоат, пропілпарагідроксибензоат, кількісне визначення, комбіновані засоби, гепатозахиста дія

\section{Introduction}

The loratadine syrup is one of the most commonly used medicines widely used in the treatment of allergic conditions in adults and children. Somewhat restricting its use, the presence of side effects, in particular among drug poisoning, one of the leading places in children and adults is occupied by loratadine-induced changes in the liver $[1,2]$. In order to eliminate unwanted effects on the liver, it is expedient to combine with phytocomponent, which shows hepatoprotective action.

2. Formulation of the problem in a general way, the relevance of the theme and its connection with important scientific and practical issues

Among the plant substances were found a lot of very effective hepatoprotectors. In medical practice, widely used preparations of plant origin are Silibor,
Gepabene, Essentiale, etc. High hepatoprotective activity on different models of liver damage was found in plants such as spotted thistle (seed) [3], artichoke (baskets), pumpkin common (seed oil) [4], agave americana (leaves) [5], greater celandine (grass), dandelion (roots), peppermint (leaves) [6, 7], turmeric (roots) [8, 9], cassia acutifolia (leaves), etc. [10]. Our previous studies have shown that the plant extracts of artichoke, fumitory schleicheri, Bupleurum aureum grass, Salsola collina grass contribute to the prevention of hepatotoxic effects of loratadine $[11,12]$. The choice of plants for research is based on the algorithm developed by us [13]. According to experimental data, the best way of hepatoprotective action on models of toxic lesion of the liver with loratadine was the aqueous extract of a Bupleurum aureum grass. On the basis of the conducted researches the composition and tech- 
nology of the combined syrup "Loratadin+" with this plant extract [14] was developed.

\section{Analysis of recent studies and publications in} which a solution of the problem are described and to which the author refers

The chemical components of the developed combined syrup, which must be quantified, are loratadine, as well as preservatives - methyl parahydroxybenzoate and propyl parahydroxybenzoate. Different methods are used to determine loratadine, the HPLC method is the most commonly used for determining loratadine in dosage forms. Scientists [15] developed a method for quantitative determination of loratadine in tablets using a UV detector $(248 \mathrm{~nm})$, simultaneous determination of loratadine with other drugs - Guaifenesin, Ambroxol - in dosage forms in isocratic elution mode [16].

4. The field of research considering the general problem, which is described in the article

For the pharmaceutical development and preclinical studies, standardization of the obtained combined syrup should be carried out. At the same time it is advisable for the manufacturer, from the economic point of view and for safety reasons of the production personnel, to determine the active and auxiliary substances in a single sample, which reduces the time of analysis and allows you to save reagents and equipment resources. Since for the definition of plant components is more correct the summary definition of BAS groups that provide the effect, a spectrophotometric technique will be developed for them.

\section{Formulating the goals (tasks) of the article}

The aim of the present study was to develop a method for the simultaneous determination of loratadine and auxiliary substances - methylparahydroxybenzoate and propylparahydroxybenzoatein combination syrup in the presence of a Bupleurum aureum grass extract.

\section{Presentation of the main research material} (methods and objects) with the justification of the results

\section{Equipment}

Liquid chromatography separation was performed using a Shimadzu Nexera X2 LC-30AD HPLC system (Shimadzu, Japan) composed of a quaternary pump, an on-line degasser, a column temperature controller, the SIL-30AC autosampler (Shimadzu, Japan); the CTO20AC thermostat (Shimadzu, Japan) as well as the SPDM20A diode array detector (DAD). Another instruments such as Ultrasonic Cleaner Set for ultra-sonication using (Wise Clean WUC-A06H, WitegLabortechnik GmbH, Germany), Libra UniBloc AUW120D (Shimadzu Analytical Scale, Japan); class A analytical vassals that meets requirements of the $\mathrm{SPhU}(\mathrm{SPhU}, 2015)$ were used in the investigation.

\section{Reagents}

HPLC grade acetonitrile (Sigma-Aldrich GmbH, Switzerland), were used in the analysis work. HPLC grade water was obtained from a water purifying system (Millipore, Bedford, MA, USA). Other chemicals and solvents were of analytical grade.

\section{Identification}

In test solution chromatogram obtained in quantitative determination of loratadine, methylparahydroxybenzoate and propylparahydroxybenzoate, the retention times of peaks loratadine, methylparahydroxybenzoate and propylparahydroxybenzoateshould coincide with times holding the peaks in the chromatogram solution (loratadine, methylparahydroxybenzoate, propylparahydroxybenzoate) (Fig. 1, 2).

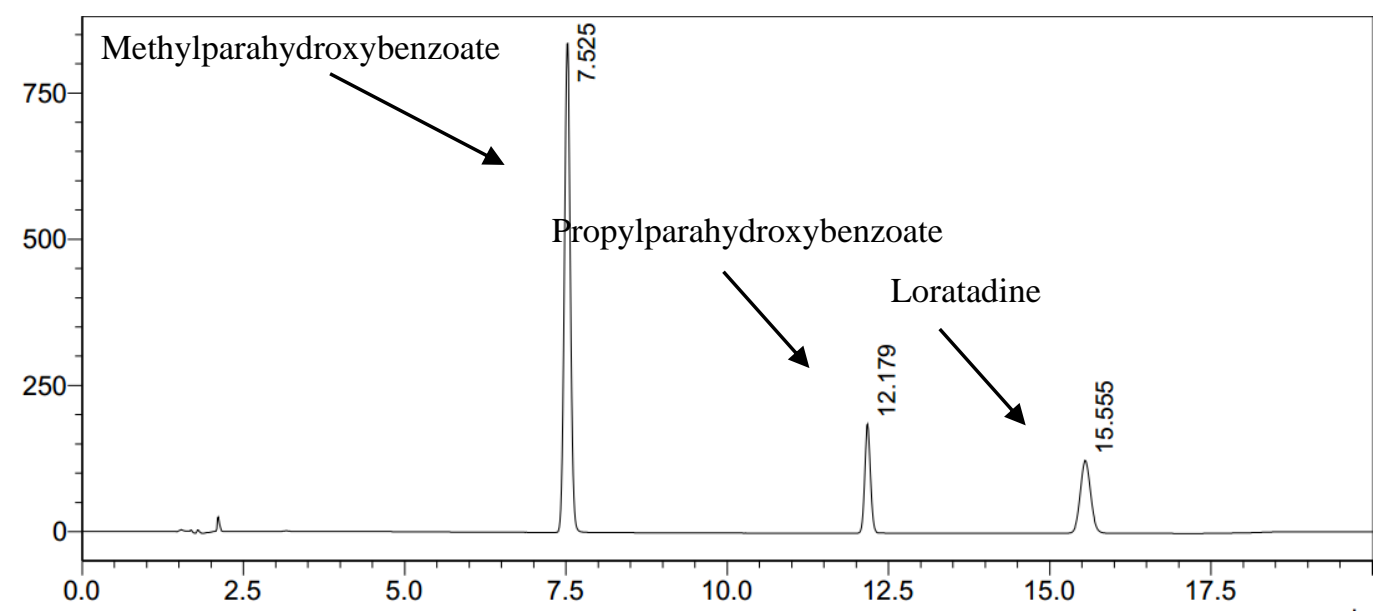

Fig. 1. Typical chromatogram of the comparison solution 


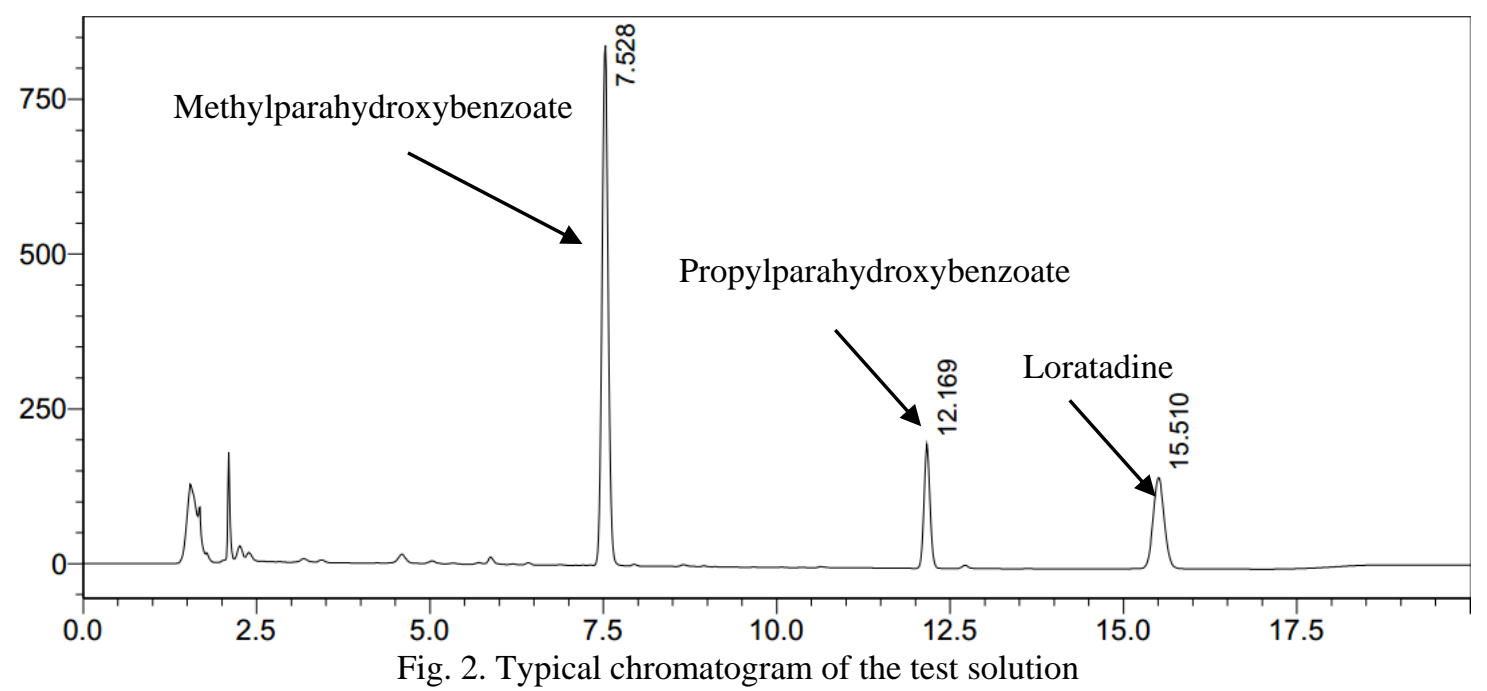

\section{Method}

Buffer solution with $p H$ 2.9. Dissolve $3.9 \mathrm{~g}$ of sodium dihydrogen phosphate in $950 \mathrm{ml}$ of water $\mathrm{R}$ and bring to $\mathrm{pH} 2.9 \pm 0.05$ with acid phosphate-soluble $\mathrm{P}$ and bring to the volume of $1000.0 \mathrm{ml}$ with the same solvent and mix.

Test solution. $2.4 \mathrm{~g}$ (precise weight) of the preparation "Loratadine + " is placed in a $20 \mathrm{ml}$ volumetric flask, $10 \mathrm{ml}$ of methanol $\mathrm{P}$ is added and shaken at a speed of $400 \mathrm{rpm}$ for 15 minutes, and then brought to the label with the same solvent and carefully mix up.

Comparison solution a. $50 \mathrm{mg}$ (precise weight loss) of lactic acid RS is placed in a volumetric flask of $50.0 \mathrm{ml}$, dissolved in $35 \mathrm{ml}$ of methanol $\mathrm{P}$ and brought to the label with the same solvent.

Comparison solution $b .80 \mathrm{mg}$ (precise weight gain) of RS methyl parahydroxybenzoate $\mathrm{P}$ is placed in a volumetric flask of $50.0 \mathrm{ml}$, dissolved in $35 \mathrm{ml}$ of methanol $\mathrm{P}$ and brought to the label with the same solvent.

Comparison solution c. $40 \mathrm{mg}$ (precise weight loss) of RS propylparahydroxybenzoate $\mathrm{P}$ is placed in a volumetric flask of $100.0 \mathrm{ml}$ and dissolved in $60 \mathrm{ml}$ of methanol $\mathrm{P}$ and brought to the label with the same solvent.

Comparative solution d. $5.0 \mathrm{ml}$ of the comparison solution a, $5.0 \mathrm{ml}$ of the comparison solution in 5.0 and the solution of comparison with transfer to a volumetric flask of $50 \mathrm{ml}$ capacity, bring with the methanol $\mathrm{P}$ to the volume and mix thoroughly.

Placebo-extract solution. $68 \mathrm{mg}$ of a dry extract of a Bupleurum aureum grass was placed in a volumetric flask of $20.0 \mathrm{ml}, 10 \mathrm{ml}$ of methanol $\mathrm{R}$ was added and shaken at a speed of $400 \mathrm{rpm}$ for 15 minutes, and then brought to the label with the same solvent and mixed thoroughly.

The solutions are filtered through a membrane filter with a pore diameter of $0.45 \mu \mathrm{m}$.
Chromatography is carried out on a liquid chromatograph with a spectrophotometric detector under the following conditions:

- column with a size of $150 \times 4.6 \mathrm{~mm}$, filled with silica gel octadecylsilylene for chromatography $\mathrm{P}$ (for example, ACE C18, size $150 \times 4.6 \mathrm{~mm}$, YMC company) with a pre-column, with a particle size of $5 \mu \mathrm{m}$, for which the conditions of suitability of the chromatographic system are fulfilled;

- speed of the mobile phase: $1.0 \mathrm{ml} / \mathrm{min}$;

- column temperature: $35^{\circ} \mathrm{C}$;

- detection at wavelength: $270 \mathrm{~nm}$;

- volume of injection: $10 \mu \mathrm{l}$;

- mobile phase A: buffer solution with pH 2.9;

- mobile phase $\mathrm{B}$ : acetonitrile $\mathrm{P}$;

- gradient program:

Time, min $\quad$ Mobile phase A, \% Mobile phase B, \%

$\begin{array}{ccc}0: 00 & 80 & 20 \\ 02: 00 & 80 & 20 \\ 10: 00 & 55 & 45 \\ 15: 00 & 55 & 45 \\ 16: 00 & 80 & 20 \\ 20: 00 & 80 & 20\end{array}$

Alternately chromatograph solution of comparison $\mathrm{d}$ and test solution at least 5 times.

The chromatographic system is considered to be suitable if the following conditions are met for the comparison solution:

- the efficiency of the chromatographic column, calculated at the peaks of the main substances, should be at least 3000 theoretical plates;

- the peak symmetry ratio must be in the range from 0.8 to 1.5 ;

- the relative standard deviation for peak areas, should not exceed $1.0 \%$, calculated on the results of 5 injections.

Table 1

Parameters of the chromatographic system that were found during the analysis

\begin{tabular}{|l|c|c|c|}
\hline \multicolumn{1}{|c|}{ Substance } & $\begin{array}{c}\text { Efficiency } \\
\text { (number of theoretical plates) }\end{array}$ & $\begin{array}{c}\text { Symmetry } \\
\text { factor }\end{array}$ & Relative standard deviation, \% \\
\hline Loratadine & 40756 & 1.06 & 0.14 \\
\hline Methylparahydroxybenzoate & 25318 & 1.04 & 0.17 \\
\hline Propylparahydroxybenzoate & 71188 & 1.07 & 0.05 \\
\hline
\end{tabular}


The content of loratadine $\left(\mathrm{X}_{1}\right)$ in $1 \mathrm{ml}$ of the drug, in milligrams, was calculated by the formula:

$$
X_{1}=\frac{S_{i} \times m_{0} \times 20 \times 5 \times \rho \times P}{S_{0} \times m_{1} \times 50 \times 50 \times 100}=\frac{S_{i} \times m_{0} \times \rho \times P}{S_{0} \times m_{1} \times 2500},
$$

where $S_{i}$ - average value of loratadine peak area, calculated from the chromatograms of the test solution;

$\mathrm{S}_{0}-$ average value of peak areas of loratadine, calculated from the chromatogram of the comparison solution $(\mathrm{d})$;

$\mathrm{m}_{0}$ - weight of drug, in grams;

$\mathrm{m}_{1}$ - weight of loratadine, in milligrams;

$\rho$ - density of drug, in $\mathrm{g} / \mathrm{cm}^{3}$;

$\mathrm{P}$ - the content of the main substance in loratadine, as a percentage.

The content of methylparahydroxybenzoate $\left(\mathrm{X}_{2}\right)$ in $1 \mathrm{ml}$ of the drug, in milligrams, was calculated by the formula:

$$
X_{2}=\frac{S_{i} \times m_{0} \times 20 \times 5 \times \rho \times P}{S_{0} \times m_{2} \times 50 \times 50 \times 100}=\frac{S_{i} \times m_{0} \times \rho \times P}{S_{0} \times m_{2} \times 2500},
$$

where $S_{i}$ - average value of methylparahydroxybenzoate peak area, calculated from the chromatograms of the test solution;

$\mathrm{S}_{0}$ - average value of peak areas of methylparahydroxybenzoate, calculated from the chromatogram of the comparison solution (d);

$\mathrm{m}_{0}$ - weight of drug, in grams; milligrams;

$m_{1}$ - weight of methylparahydroxybenzoate, in

$\rho$ - density of drug, in $\mathrm{g} / \mathrm{cm}^{3}$;

$\mathrm{P}$ - the content of the main substance in methylparahydroxybenzoate, as a percentage;

The content of propylparahydroxybenzoate $\left(\mathrm{X}_{3}\right)$ in $1 \mathrm{ml}$ of the drug, in milligrams, was calculated by the formula:

$$
X_{3}=\frac{S_{i} \times m_{0} \times 20 \times 5 \times \rho \times P}{S_{0} \times m_{3} \times 100 \times 50 \times 100}=\frac{S_{i} \times m_{0} \times \rho \times P}{S_{0} \times m_{3} \times 5000}
$$

where $S_{i}$ - average value of propylparahydroxybenzoate peak area, calculated from the chromatograms of the test solution;

$\mathrm{S}_{0}$ - average value of peak areas of propylparahydroxybenzoate, calculated from the chromatogram of the comparison solution (d);

$\mathrm{m}_{0}$ - weight of drug, in grams; milligrams;

$\mathrm{m}_{1}$ - weight of propylparahydroxybenzoate, in

$\rho$-density of drug, in $\mathrm{g} / \mathrm{cm}^{3}$;

$\mathrm{P}$ - the content of the main substance in propylparahydroxybenzoate, as a percentage;

\section{Discussion of the results}

At the beginning of the development of the technique, we tried to use the technique of isocratic elution of the components of the mixture. In this case, the following conditions were used: the stationary phase - a measuring column $150 \times 4.6 \mathrm{~mm}$, filled with silica gel octylsilyl for chromatography $\mathrm{P}$ with a pre-column, with a particle size of $5 \mu \mathrm{m}$; speed of the mobile phase: $2.0 \mathrm{ml} / \mathrm{min}$; column temperature: $35^{\circ} \mathrm{C}$; detection at wavelength: $254 \mathrm{~nm}$; volume of injection: $20 \mu \mathrm{l}$; mobile phase A: buffer solution with $\mathrm{pH} 2.9$ (3.9 g sodium dihydrogen phosphate $\mathrm{P}$ is dissolved in $900 \mathrm{ml}$ of water for chromatography $\mathrm{P} . \mathrm{pH}$ is set to $2.9 \pm 0.1$ with the aid of phosphoric acid $\mathrm{P}$ and the volume of water solution is adjusted to a $\mathrm{pH}$ of $1000 \mathrm{ml}$ for water chromatography); mobile phase B: acetonitrile $\mathrm{P}$; ratio between mobile phases $(1: 1)$

It has been found that this system has a low resolution for the methylparahydroxybenzoate peak with other components present in the matrix. To improve the resolution, the mobile phase speed was reduced to $1.5 \mathrm{ml} / \mathrm{min}$ and the amount of phase B (acetonitrile) to $45 \%$, as well as the injection volume was reduced to $10 \mu \mathrm{l}$. However, these changes did not eliminate the problem and as shown in the following figure, the peak of methylparahydroxybenzoate does not have a satisfactory separation with the peaks of substances present in the preparation.

Therefore, the speed of the mobile phase was reduced to $1.0 \mathrm{ml} / \mathrm{min}$, and the concentration of the mobile phase $\mathrm{B}$ to $40 \%$. After chromatography of the test solution under altered conditions, it was observed that the separation between the peaks improved, but still remained unacceptable. To solve this problem, it was decided to use a gradient mode to improve separation between substances, and it was also decided to change the wavelength for detecting from $254 \mathrm{~nm}$ to $270 \mathrm{~nm}$ to increase the specificity, since loratadine, methylparahydroxybenzoate and propylparahydroxybenzoate had a sufficient absorption at a given wavelength, while other components of the drug had less effect during the analysis. Using a gradient mode, a better separation between compounds was observed, the separation factor between the peaks of the methylparahydroxybenzoate and its nearest peaks was greater than 2.5 , in the case of propyl parahydroxybenzoate this figure was greater than 3 .

To confirm the correctness of the proposed method, validation studies were carried out in accordance with the requirements of the SPHU.

Forecast of uncertainty of analysis results

In the drug "Loratadine+" the quantitative content of its components should be within $\pm 5 \%$, therefore:

$$
\Delta \mathrm{AS} \leq \frac{95-105}{2} \times 0,32=1,6 \%
$$

We have calculated the uncertainty of sample preparation for loratadine, methylparahydroxybenzoate and propylparahydroxybenzoate when determined by HPLC. It is found to be $1.5 \%$ for loratadine, $1.47 \%$ for methylparahydroxybenzoate, $1.53 \%$ for propylparahydroxybenzoate, which does not exceed the eligibility criterion.

\section{Specificity}

For the study of specificity were prepared solutions: solvent (blank solution), solutions of the comparison, the extract and the test solution.

The specificity of the method is confirmed by comparing the chromatogram with the comparison solution, the test solution, and the blank solution chromatogram. The retention times of loratadine, methylparahydroxybenzoate 
and propylparahydroxybenzoate peaks on the chromatograms of the test solution correspond to the retention time of loratadine, methylparahydroxybenzoate and propylparahydroxybenzoate peaks on the chromatogram of the comparison solution. No peaks were found on the chromatogram form, the retention time of which would coincide with the peaks of loratadine, methylparahydroxybenzoate and propylparahydroxybenzoate retention times.

\section{Linearity}

To confirm the linearity of the method, 9 model solutions of each component were prepared in appropri- ate concentrations, which varied evenly within the range of application (step - $5 \%$ ).

$$
X_{i}=C_{i} / C_{s t} \cdot 100 \text { та } Y_{i}=S_{i} / S_{s t} \cdot 100 .
$$

According to the data obtained (Fig. 3, Tab. 2), the linearity of the methodology is performed throughout the concentration range for loratadine and both auxiliary substances.

The correlation coefficients are $0.9999,0.9999$ and 0.9995 , respectively.

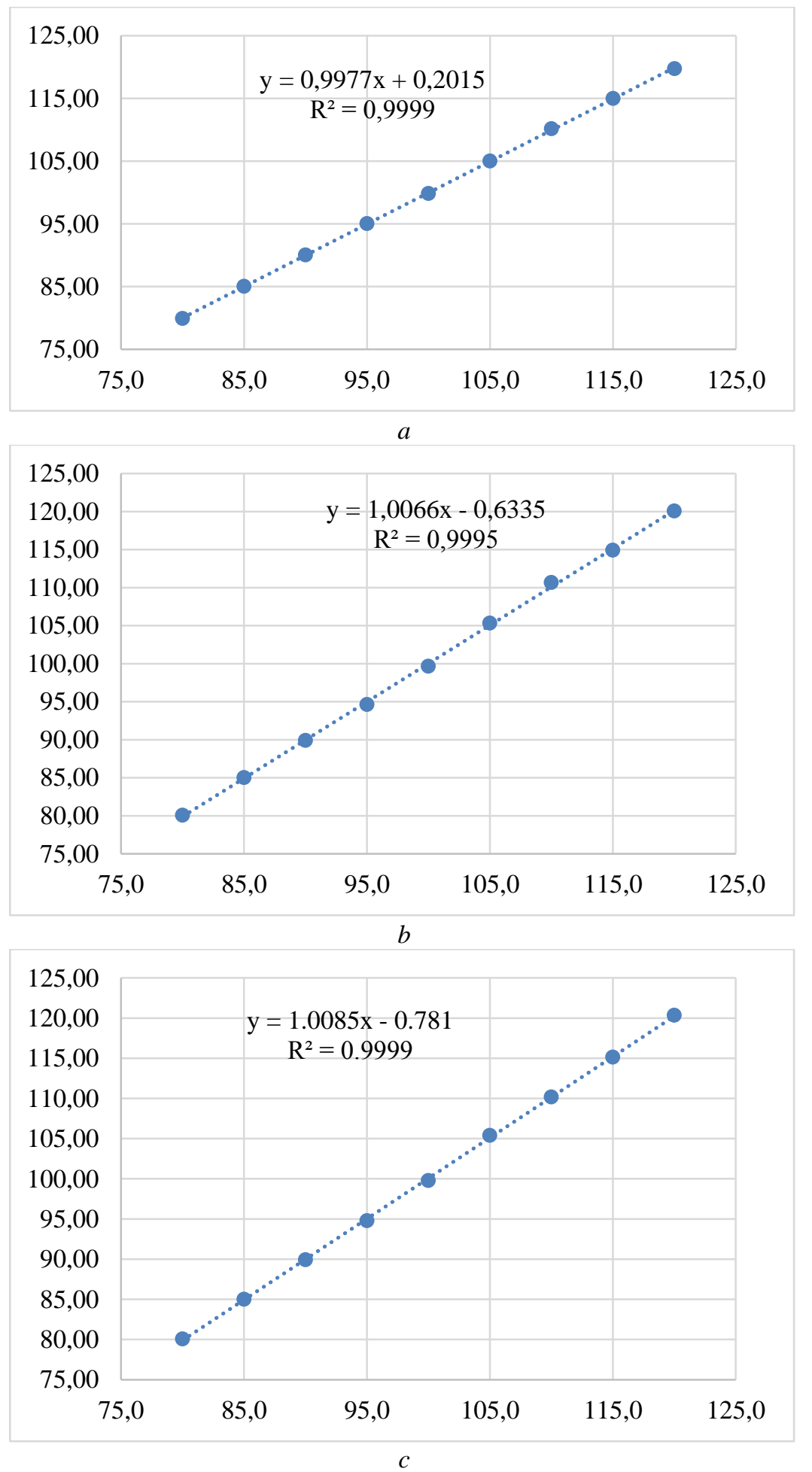

Fig. 3. Charts of the linear dependence of the analytical signal on the actual concentration of solution in the normalized coordinates for: $a$-methylparahydroxybenzoate; $b$-propylparahydroxybenzoate; $c$ - loratadine 
Data validation of the linearity of the method of quantitative determination

\begin{tabular}{|c|c|c|c|c|}
\hline $3 / \Pi$ & Parameter & Requirements & The resulting value & Execution of the criterion \\
\hline \multicolumn{5}{|c|}{ Methylparahydroxybenzoate } \\
\hline 1 & $\mathrm{a}$ & $\leq 2.6$ & 0.2015 & Executed \\
\hline 2 & $\mathrm{~S}_{0}$ & $\leq 0.84$ & 0.15 & Executed \\
\hline 3 & $\mathrm{r}$ & $>0,9981$ & 0.9999 & Executed \\
\hline \multicolumn{5}{|c|}{ Propylparahydroxybenzoate } \\
\hline 1 & $\mathrm{a}$ & $\leq 2.6$ & 0.6335 & Executed \\
\hline 2 & $\mathrm{~S}_{0}$ & $\leq 0.84$ & 0.31 & Executed \\
\hline 3 & $\mathrm{r}$ & $>0.9981$ & 0.9995 & Executed \\
\hline \multicolumn{5}{|c|}{ Loratadine } \\
\hline 1 & $\mathrm{a}$ & $\leq 2.6$ & 0.781 & Executed \\
\hline 2 & So & $\leq 0.84$ & 0.21 & Executed \\
\hline 3 & $\mathrm{r}$ & $>0.9981$ & 0.9999 & Executed \\
\hline
\end{tabular}

According to the results of the linearity study, the technique is correct for all determined components.

\section{Correctness}

To determine the correctness within the range of the use of the analytical method, 9 test solutions were prepared, with all stages of the analytical technique fol- lowed. The rule is characterized by two criteria - practical and statistical insignificance, which were determined during the experimental research (Table 3 ).

The fulfilment of the correctness criteria by the two criteria is given in Table 4. By the correctness parameter methodology is correct.

Table 3

Results of determining the correctness of the method $(n=9)$

\begin{tabular}{|c|c|}
\hline \multicolumn{2}{|l|}{ Methylparahydroxybenzoate } \\
\hline 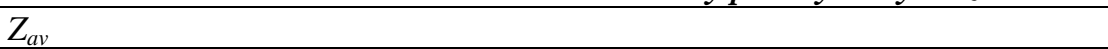 & 99.98 \\
\hline Relative standard deviation, $\mathrm{s}_{\mathrm{z}} \%$ & 0.11 \\
\hline $\begin{array}{l}\text { Relative confidence interval } \\
\Delta Z=t(95 \%, 8) *_{z}=1.8595 *_{s_{z}}=\end{array}$ & 0.21 \\
\hline Critical to the convergence of results $\Delta a s \% \leq$ & 1.6 \\
\hline Systematic error $\delta \%=\left|Z_{a v}-100\right|$ & 0.02 \\
\hline $\begin{array}{l}\text { Criterion of statistical insignificance } \\
\quad \Delta \mathrm{Z} / 3=0.21 / 3=0.07(0.02 \leq 0.07) \\
\text { If not, then the criterion of practical insignificance, } \delta \% \leq 0.512(0.02 \leq 0.512)\end{array}$ & $\begin{array}{l}\text { Executed } \\
\text { Executed }\end{array}$ \\
\hline General conclusion about the methodology & Correct \\
\hline \multicolumn{2}{|l|}{ Propylparahydroxybenzoate } \\
\hline$Z_{a v}$ & 100.01 \\
\hline Relative standard deviation, sz \% & 0.31 \\
\hline $\begin{array}{l}\text { Relative confidence interval } \\
\Delta \mathrm{Z}=\mathrm{t}(95 \%, 8) * \mathrm{sZ}=1.8595 * \mathrm{sZ}=\end{array}$ & 0.57 \\
\hline Critical to the convergence of results $\Delta$ as $\% \leq$ & 1.6 \\
\hline Systematic error $\delta \%=\left|Z_{a v}-100\right|$ & 0.01 \\
\hline $\begin{array}{l}\text { Criterion of statistical insignificance } \\
\Delta \mathrm{Z} / 3=0.57 / 3=0.19(0.01 \leq 0.19) \\
\text { If not, then the criterion of practical insignificance, } \delta \% \leq 0.512(0.01 \leq 0.512)\end{array}$ & $\begin{array}{l}\text { Executed } \\
\text { Executed }\end{array}$ \\
\hline General conclusion about the methodology & Correct \\
\hline \multicolumn{2}{|l|}{ Loratadine } \\
\hline$Z_{a v}$ & 100.06 \\
\hline Relative standard deviation, sz \% & 0.21 \\
\hline $\begin{array}{l}\text { Relative confidence interval } \\
\Delta \mathrm{Z}=\mathrm{t}(95 \%, 8) * \mathrm{sz}=1.8595 * \mathrm{sz}=\end{array}$ & 0.39 \\
\hline Critical to the convergence of results $\Delta$ as $\% \leq$ & 1.6 \\
\hline Systematic error $\delta \%=\left|Z_{a v}-100\right|$ & 0.06 \\
\hline $\begin{array}{l}\text { Criterion of statistical insignificance } \\
\Delta \mathrm{Z} / 3=0.39 / 3=0.13(0.06 \leq 0.13) \\
\text { If not, then the criterion of practical insignificance, } \delta \% \leq 0.512(0.06 \leq 0.512)\end{array}$ & Executed \\
\hline General conclusion about the methodology & Correct \\
\hline
\end{tabular}


Results of validation by two criteria

\begin{tabular}{|c|c|c|c|c|}
\hline Parameter & Value & $\begin{array}{c}\text { Requirements for statisti- } \\
\text { cal insignificance }\end{array}$ & $\begin{array}{c}\text { Requirements for practical } \\
\text { insignificance }\end{array}$ & $\begin{array}{c}\text { Execution of the } \\
\text { criterion }\end{array}$ \\
\hline \multicolumn{7}{|c|}{ Methylparahydroxybenzoate } \\
\hline $\mid \bar{Z}-100$ & 0.02 & $\leq 0.07$ & $\leq 0.512$ & $\begin{array}{c}\text { Followed by two } \\
\text { criteria }\end{array}$ \\
\hline \multicolumn{7}{|c|}{ Propylparahydroxybenzoate } \\
\hline $\mid \bar{Z}-100$ & 0.01 & $\leq 0.19$ & $\leq 0.512$ & $\begin{array}{c}\text { Followed by two } \\
\text { criteria }\end{array}$ \\
\hline \multicolumn{7}{|c|}{ Loratadine } \\
\hline
\end{tabular}

\section{In-laboratory precision}

To determine, the results of a study of 6 samples of one sample by two analysts were used on different days for one working week using different measuring dishes. The results are shown in the Table. 5-7. Results of evaluation of laboratory precision are given in Table. 8 show that the obtained values of the confidence interval of the average result meet the eligi bility criterion (not more than 1.6).

Table 5

Determination of intra-laboratory precision parameters for methylparahydroxybenzoate

\begin{tabular}{|c|c|c|}
\hline No. & Analyst No. 1 & Analyst No. 2 \\
\hline 1 & 97.68 & 97.45 \\
\hline 2 & 97.53 & 97.37 \\
\hline 3 & 97.33 & 97.10 \\
\hline 4 & 97.77 & 97.22 \\
\hline 5 & 97.61 & 97.46 \\
\hline 6 & 97.58 & 97.32 \\
\hline Average & 97.58 & 97.32 \\
\hline Dispersion, $\mathrm{s}^{2}$ & 0.038 & 0.031 \\
\hline \multicolumn{2}{|c|}{ Overall average } & 97.45 \\
\hline \multicolumn{2}{|c|}{ Relative standard deviation, RSD \% } & 0.13 \\
\hline \multicolumn{2}{|c|}{ Confidence interval, $(\Delta$ intra $=\mathrm{t}(95 \%, \mathrm{~m} * \mathrm{n}-1) * \mathrm{RSD}, \%=1,7956 * \mathrm{RSD}, \%$} & 0.27 \\
\hline
\end{tabular}

Table 6

Determination of intra-laboratory precision parameters for propylparahydroxybenzoate

\begin{tabular}{|c|c|c|}
\hline & Analyst No. 1 & Analyst No. 2 \\
\hline No. & 101.43 & 101.19 \\
\hline 1 & 101.83 & 101.22 \\
\hline 2 & 101.26 & 101.20 \\
\hline 3 & 102.11 & 101.44 \\
\hline 4 & 101.74 & 101.39 \\
\hline 5 & 101.67 & 101.29 \\
\hline 6 & 101.67 & 101.29 \\
\hline Average & 0.150 & 0.019 \\
\hline Dispersion, s & 101.48 \\
\hline \multicolumn{2}{|c|}{ Overall average } & 0.19 \\
\hline Relative standard deviation, RSD \% & 0.38 \\
\hline
\end{tabular}

Table 7

Determination of intra-laboratory precision parameters for loratadine

\begin{tabular}{|c|c|c|}
\hline No. & Analyst No. 1 & Analyst No. 2 \\
\hline 1 & 100.898 & 100.524 \\
\hline 2 & 100.853 & 100.750 \\
\hline 3 & 101.083 & 100.207 \\
\hline 4 & 100.800 & 100.233 \\
\hline 5 & 100.426 & 100.035 \\
\hline 6 & 100.812 & 100.349 \\
\hline Average & 100.812 & 100.350 \\
\hline Dispersion, $\mathrm{s}^{2}$ & 0.077 & 0.108 \\
\hline \multicolumn{2}{|c|}{ Overall average } & 100.581 \\
\hline \multicolumn{2}{|c|}{ Relative standard deviation, RSD \% } & 0.230 \\
\hline \multicolumn{2}{|c|}{ Confidence interval, $\left(\Delta\right.$ intra $=\mathrm{t}\left(95 \%, \mathrm{~m}^{*} \mathrm{n}-1\right) * \mathrm{RSD}, \%=1,7956 * \mathrm{RSD}, \%$} & 0.463 \\
\hline
\end{tabular}


Results of evaluation of in-laboratory precision

\begin{tabular}{|c|c|c|c|}
\hline Parametr & Requirements of the criterion & The resulting value & Execution of the criterion \\
\hline \multicolumn{4}{|c|}{ Methylparahydroxybenzoate } \\
\hline$\Delta$ intra & $\leq 1,6$ & 0.27 & Executed \\
\hline \multicolumn{4}{|c|}{ Propylparahydroxybenzoate } \\
\hline$\Delta$ intra & $\leq 1,6$ & 0.380 & Executed \\
\hline \multicolumn{4}{|c|}{ Loratadine } \\
\hline$\Delta$ intra & $\leq 1,6$ & 0.463 & Executed \\
\hline
\end{tabular}

\section{Robustness (stability)}

The stability of the standard solution and the test solution was studied after 24 hours (Tab. 9, 10).

Table 9

Determination of the stability of the standard solution

\begin{tabular}{|c|c|c|c|}
\hline $\begin{array}{c}\text { Substance } \\
\text { Methylparahy- } \\
\text { droxybenzoate }\end{array}$ & $\begin{array}{c}\text { Average value of S peak of } \\
\text { freshly prepared solution }\end{array}$ & $\begin{array}{c}\text { Average value of S peak of } \\
\text { solution after 24 h }\end{array}$ & $\begin{array}{c}\text { Parameter change in per- } \\
\text { centages after 24 hours }\end{array}$ \\
\hline $\begin{array}{c}\text { Propylparahy- } \\
\text { droxybenzoate }\end{array}$ & 5421695 & 5423838 & 0.040 \\
\hline Loratadine & 1153291 & 1149287 & 0.347 \\
\hline
\end{tabular}

Table 10

Determination of the stability of the test solution

\begin{tabular}{|c|c|c|c|}
\hline Substance & $\begin{array}{c}\text { Average value of S peak of } \\
\text { freshly prepared solution }\end{array}$ & $\begin{array}{c}\text { Average value of S peak of } \\
\text { solution after 24 h }\end{array}$ & $\begin{array}{c}\text { Parameter change in per- } \\
\text { centages after 24 hours }\end{array}$ \\
\hline $\begin{array}{c}\text { Methylparahy- } \\
\text { droxybenzoate }\end{array}$ & 5244979 & 5243940 & 0.020 \\
\hline $\begin{array}{l}\text { Propylparahy- } \\
\text { droxybenzoate }\end{array}$ & 1221627 & 1226178 & 0.373 \\
\hline Loratadine & 1644919 & 1648117 & 0.194 \\
\hline
\end{tabular}

Differences between the obtained values of peak areas should exceed the criterion of insignificance in comparison with the maximum permissible uncertainty of the analysis results ( $\triangle \mathrm{AS}$, insig), that is $0.512 \%$.

As a result of the determination, it has been determined that for optimal chromatographic conditions, freshly prepared solution for comparison can be used within 24 hours.
7. Conclusions from the conducted research and prospects for further development of this field

1. The method of simultaneous quantitative determination of loratadine and auxiliary substances - methylparahydroxybenzoate and propylparahydroxybenzoate in a combined syrup "Loratadine+" has been developed.

2. Conditions are defined that allow correctly determining all components in the presence of a Bupleurum aureum grass extract. The correctness of the methodology is confirmed by validation studies.

\section{References}

1. Antihistamine-Induced Hepatitis: 2 Cases Involving Loratidine / Arshad H., Khan A., Assad U., Kittaneh M., Berkelhammer C. // Case Reports in Hepatology. 2016. Vol. 2016. P. 1-2. doi: http://doi.org/10.1155/2016/6890313

2. Breidak O. O., Kuzminov O. B. Otsinka kumuliatyvnoi aktyvnosti diazolinu, loratydynu ta dezloratydynu u pidhostromu ekspyrementi na bilykh myshakh // Biolohiia tvaryn. 2015. Vol. 17, Issue 4. P. 178.

3. Farmakoterapevticheskie effekty i klinicheskie vozmozhnosti etalonnogo preparata silimarina / Gubergic N. B., Fomenko P. G., Lukashevich G. M., Golubova O. A. // FARMATEKA. 2012. Issue 2. P. 24-31.

4. Rastitelnye masla. Sostav i perspektivy ispolzovaniia masla semian tykvy Cucurbita Pepo v terapii (obzor) / Pegova R. A., Vorobeva O. A., Kolchik O. V., Bolshakova A. E., Zhilcova O. E., Melnikova N. B. // Medicinskii almanakh. 2014. Issue 2 (32). P. $127-135$.

5. Medicinal plants with hepatoprotective activity in Iranian folk medicine / Asadi-Samani M., Kafash-Farkhad N., Azimi N., Fasihi A., Alinia-Ahandani E., Rafieian-Kopaei M. // Asian Pacific Journal of Tropical Biomedicine. 2015. Vol. 5, Issue 2. P. 146157. doi: http://doi.org/10.1016/s2221-1691(15)30159-3

6. Zhuravlova L. V., Kryvonosova O. M. Porivnialna kharakterystyka hepatoprotektornykh zasobiv: kliuch do ratsionalnoho zastosuvannia // Suchasna hastroenterolohiia. 2013. Issue 4 (72). P. 35-41.

7. Hepatotoxicity: Treatment, causes and applications of medicinal plants as therapeutic agents / Thompson M., Jaiswal Y., Wang I., Williams L. // The Journal of Phytopharmacology. 2017. Vol. 6, Issue 3. P. 186-193. 
8. Majee C., Mazumder R., Choudhary A. N. Medicinal plants with anti-ulcer and hepatoprotective activity // International Journal of pharmaceutical sciences and research. 2019. Vol. 10, Issue 1. P. 1-11. doi: http://doi.org/10.13040/ijpsr.09758232.10(1).1-11

9. Deshwal N., Sharma A. K., Sharma P. Review on hepatoprotective plants // International Journal of Pharmaceutical Sciences Review and Research. 2011. Vol. 7, Issue 1. P. 15-26.

10. The hepatoprotective effect of Cassia fistula leaves in Isoniazid and rifampicin induced hepatotoxicity in rodents / Jehangir A., Nagi A. H., Shahzad M. S., Azam Z. // Biomedica. 2010. Vol. 26. P. 25-29.

11. Björnsson E. Hepatotoxicity by Drugs: The Most Common Implicated Agents // International Journal of Molecular Sciences. 2016. Vol. 17, Issue 2. P. 224. doi: http://doi.org/10.3390/ijms17020224

12. Antioxidation properties of extracts of aerial part of Bupleurum aureum, Hill-growing soltword herb, Fumaria Schleicheri and Cynara scolymus in vitro and in vivo / Naboka O. I., Khouari S., Glushchenko A. V., Georgiyants V. A. // Journal of Chemical and Pharmaceutical Research. 2014. Vol. 6, Issue 7. P. 172-177.

13. Glushchenko A., Vladymyrova I., Georgiyants V. The substantiation of the selection of medicinal plants and their rational application in diseases of the hepatobiliary system // ScienceRise: Pharmaceutical Science. 2018. Vol. 2, Issue 12. P. 9-16. doi: http://doi.org/10.15587/2519-4852.2018.129642

14. Sposob vvedeniia sukhogo ekstrakta volodushki zolotistoi v sirop «Loratadin»/Glushchenko A. V., Puliaev D. S., Georgiianc V. A., Naboka O. I. // Vestnik farmacii. 2016. Issue 4 (74). P. 6-9.

15. Rozrobka i validatsiia metodyk identyfikatsii loratadynu v tabletkakh / Korobko D. B., Poliak O. B., Lohoida L. S., Zarivna N. O., Semianiv O. V. // Aktualni pytannia farmatsevtychnoi i medychnoi nauky ta praktyky. 2014. Issue 1 (14). P. 55-58.

16. Florin A., Grigoriv I. C., Ciobanu C. Validation and Application of a RP-HPLC Method with UV Detection for Loratadine Determination // Revista de Chimie-Bucharest-Original Edition. 2016. Vol. 67, Issue 6. P. 1227-1231.

Дата надходження рукопису 26.03.2019

Alla Glushchenko, PhD, Associate Professor, Department of Quality, Standardization and Certification of Medicines, National University of Pharmacy, Pushkinska str., 53, Kharkiv, Ukraine, 61002

E-mail: allaglushchenko05@gmail.com

Ivan Bezruk, Postgraduate student, Department of Pharmaceutical Chemistry, National University of Pharmacy Pushkinska str., 53, Kharkiv, Ukraine, 61002

E-mail: vania.bezruk@gmail.com

Liudas Ivanauskas, PhD, Associate Professor, Head of Department, Department of Analytical and Toxicological Chemistry, Medical Academy of Lithuanian University of Health Sciences, Eivenių g., 4, Kaunas, Lithuania, LT-50161

E-mail: liudas.ivanauskas@1smuni.lt

Victoriya Georgiyants, Doctor of Pharmacy, Professor, Head of Department, Department of Pharmaceutical Chemistry, National University of Pharmacy, Pushkinska str., 53, Kharkiv, Ukraine, 61002

E-mail:vgeor@ukr.net 